ORIGINAL ARTICLE

\title{
Temporal factors in motor vehicle crash deaths
}

\section{M Farmer, A F Williams}

Injury Prevention 2005;11:18-23. doi: 10.1136/ip.2004.005439

See end of article for authors' affiliations .....................

Correspondence to: Charles M Farmer, Insurance Institute for Highway Safety, 1005 North Glebe Road, Arlington, VA 222014751,USA; cfarmer@ iihs.org

\begin{abstract}
Objective: To summarize fatal motor vehicle crash deaths in the United States by time of day, day of week, month, and season, and to determine why some days of the year tend to experience a relatively high number of deaths.

Method: Crash deaths were identified and categorized using the Fatality Analysis Reporting System. Days of the year with relatively high crash deaths were compared to the two days that occurred exactly one week before and one week after.

Results: On average, motor vehicle crashes in the United States result in more than 100 deaths per day, but there is much day-to-day variability. During 1986-2002 the single day fatality count ranged from a low of 45 to a high of 252. Summer and fall months experience more crash deaths than winter and spring, largely due to increased vehicle travel. July 4 (Independence Day) has more crash deaths on average than any other day of the year, with a relatively high number of deaths involving alcohol. January 1 (New Year's Day) has more pedestrian crash deaths on average, plus it has the fifth largest number of deaths per day overall, also due to alcohol impairment. On other days the high numbers of deaths are likely due to increases in holiday or recreational travel.

Conclusion: Every day of the year results in many crash deaths, but certain days stand out as particularly risky. The temporal and geographic spread of crash deaths, as well as the view of driving as a routine task, inures the public to this continuing problem. Innovative strategies are needed both to raise awareness and to work toward a solution.
\end{abstract}

M otor vehicle crashes in the United States result in more than 40000 deaths per year. From 1975 to 2002 there were a total of 1241796 crash deaths, ranging from a high of 51093 in 1979 to a low of 39250 in $1992 .{ }^{1}$ On average, more than 100 people are killed each day, but there is a great deal of day-to-day variability. Weekend days tend to result in more fatal crashes than midweek days, and summer months experience more fatal crashes than winter months. ${ }^{12}$

Fatal motor vehicle crashes are more prevalent during holiday periods, ${ }^{3-5}$ during which there is an increase in recreational travel as people visit family and friends. Such travel may involve long distances, unfamiliar roads, and high speeds, all characteristics associated with increased crash risk. Some recreational driving may involve alcohol. However, this type of travel also may be concentrated on interstate highways, which are by design much safer than other types of roads.

This report chronicles the temporal patterns in motor vehicle crash deaths during 1986-2002. In particular, the days of the year that tended to have the highest fatality counts are examined, as well as days with the lowest fatality counts. This 17 year period was chosen specifically to balance the effects of weekend travel. During this time period each day of the week occurred exactly 887 times, and each day of the year (except February 29) covered each day of the week at least twice.

\section{METHOD}

Electronically coded descriptions of fatal crashes that occurred during 1986-2002 were extracted from the United States Department of Transportation's Fatality Analysis Reporting System (FARS). FARS is an annual census of motor vehicle crashes occurring on public roads that result in a fatality within 30 days. Information gathered includes date and hour of the crash and characteristics of the vehicles and people involved. For the study period all fatality records contained information on the month of the crash, but 189 records did not have the exact date of the crash. Blood alcohol concentration (BAC) is often reported for drivers and pedestrians involved in fatal motor vehicle crashes. However, during the period of this study, $29 \%$ of the fatally injured drivers and $39 \%$ of the fatally injured pedestrians did not have reported BACs. For cases in which BAC is not reported the Department of Transportation uses a multiple imputation procedure to obtain estimates, which are then included in FARS. ${ }^{6}$ Vehicle miles of travel on public roads, estimated monthly, were obtained from the Federal Highway Administration. $^{7}$

Motor vehicle crash deaths, categorized by month, day, and hour of the crash, were averaged over the 17 year study period. For some of the days with relatively high crash deaths, deaths were categorized by role of the person killed, age, BAC, and time of day. For comparison, the same categorizations are given for the average of the two days that occurred exactly one week before and one week after to eliminate the confounding effects of season and day of the week.

\section{RESULTS}

There were a total of 727438 motor vehicle crash deaths in the United States during 1986-2002. August averaged the highest number of motor vehicle crash deaths per day (132) during these 17 years (table 1). In fact, the six months with the most fatalities (averaging 120 to 132 deaths per day) were the summer and fall months, June through November. January and February averaged the lowest number of deaths per day (98); however, these two months also had the lowest vehicle miles traveled per day. October and December averaged the highest death rate per mile (19.1 deaths per billion vehicle miles traveled), whereas March had the lowest rate ( 16.4 deaths per billion vehicle miles traveled).

Abbreviations: BAC, blood alcohol concentration; FARS, Fatality Analysis Reporting System 


\begin{tabular}{|lllll|}
\hline \multicolumn{4}{|l}{ Table 1 } & Crash deaths by month of year, 1986-2002 \\
\hline Month & VMT (in millions) & Deaths & $\begin{array}{l}\text { Deaths per billion } \\
\text { VMT }\end{array}$ & $\begin{array}{l}\text { Average deaths per } \\
\text { day }\end{array}$ \\
\hline January & 2996148 & 51694 & 17.3 & 98 \\
February & 2860326 & 47247 & 16.5 & 98 \\
March & 3327688 & 54645 & 16.4 & 104 \\
April & 3327528 & 55710 & 16.7 & 109 \\
May & 3534141 & 62426 & 17.7 & 118 \\
June & 3525655 & 64152 & 18.2 & 126 \\
July & 3657624 & 68099 & 18.6 & 129 \\
August & 3676891 & 69731 & 19.0 & 132 \\
September & 3365709 & 63965 & 19.0 & 125 \\
October & 3476625 & 66553 & 19.1 & 126 \\
November & 3237169 & 61145 & 18.9 & 120 \\
December & 3257765 & 62071 & 19.1 & 118 \\
\hline VMT, vehicle miles traveled. & & & \\
\hline
\end{tabular}

Saturday by far averaged the highest number of crash deaths per day (158) (fig 1). Friday had the second highest number of deaths, averaging 133 deaths per day, followed by Sunday at 132 deaths. Tuesday averaged the fewest number of deaths (95).

Crash deaths were highest during afternoon and evening hours (fig 2). The hours between $5 \mathrm{pm}$ and $7 \mathrm{pm}$ had the most fatalities, each averaging 6.6 deaths per hour. The 12 hours with the greatest number of fatalities occurred between $2 \mathrm{pm}$ and $2 \mathrm{am}$. The $4 \mathrm{am}$ hour had the fewest fatalities, with an average of 2.6 deaths.

The 10 days of the year with the highest number of crash fatalities totaled over the 17 year period are listed in table 2 . July 4 (Independence Day), although rarely experiencing the greatest number of deaths in any particular year, averaged the highest number of crash deaths (161). July 3, only one day earlier, averaged the second highest number of deaths (149). Six of the 10 days with the greatest number of deaths occurred near major American holidays: July 2-4, December 23 (Christmas), January l (New Year's Day), and September 2 (Labor Day). The remaining four days were in August, which had a greater amount of vehicle travel than any other month (table 1). Another 10 days of the year averaged between 135 and 137 deaths per day, and all were during the months of August, September, October, and December. The single date with the highest number of deaths during 19862002 was Saturday, August 9, 1986 (252 deaths).

The 10 days of the year with the fewest number of crash fatalities averaged between 91 and 94 deaths per day. All occurred in January and February, the months with the least amount of vehicle travel. January 8, with the fewest average number of deaths per day (91), follows exactly one week after January 1, one of the days with the highest number of deaths (table 2). The single date with the lowest number of

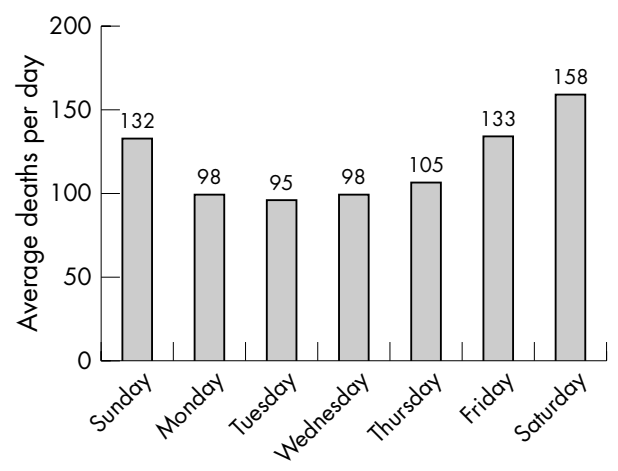

Figure 1 Crash deaths by day of week, 1986-2002.

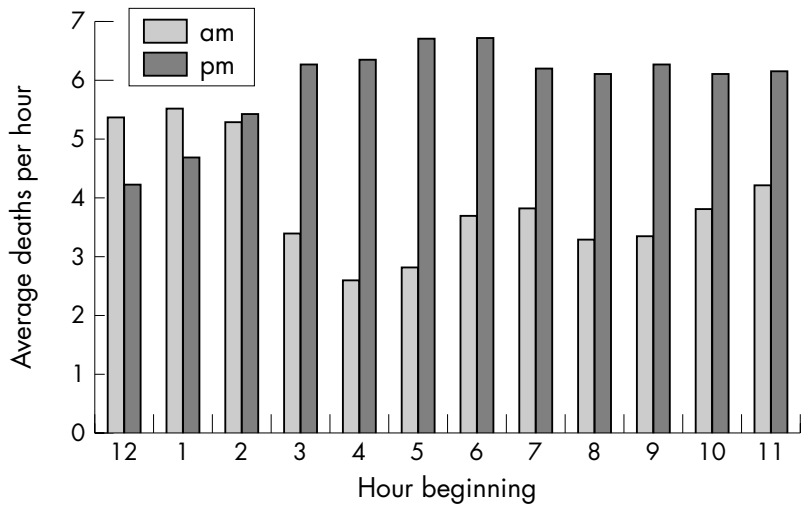

Figure 2 Crash deaths by hour of day, 1986-2002.

deaths during 1986-2002 was Monday, March 2, 1992 (45 deaths).

Motor vehicle crash deaths result from a variety of crash types. The majority of deaths (about $75 \%$ ) are to occupants of passenger vehicles (cars, pickup trucks, sport utility vehicles, and passenger/cargo vans). Table 3 lists the 10 days of the year with the most deaths to passenger vehicle occupants. July 4 had the most passenger vehicle occupant deaths on average (117), followed by December 23 (116) and January 1 (111).

Pedestrians account for about $13 \%$ of all crash deaths. The days of the year with the most pedestrian deaths on average were January 1 and October 31, each with about 24 pedestrian deaths per day (table 4). December 23 had the next highest number of pedestrian deaths ( 22 per day). All of the other days that averaged at least 20 pedestrian deaths

\begin{tabular}{lll}
$\begin{array}{l}\text { Table } 2 \\
1986-2002\end{array}$ & Days of year with most crash deaths, \\
\hline Date & Deaths & Average deaths per day \\
\hline July 4 & 2743 & 161 \\
July 3 & 2534 & 149 \\
December 23 & 2470 & 145 \\
August 3 & 2413 & 142 \\
January 1 & 2411 & 142 \\
August 6 & 2387 & 140 \\
August 4 & 2365 & 139 \\
August 12 & 2359 & 139 \\
July 2 & 2340 & 138 \\
September 2 & 2336 & 137 \\
\hline \\
Note: Highest single day fatality count during this period was \\
252 on Saturday, August 9, 1986.
\end{tabular}


Table 3 Days of year with most passenger vehicle occupant crash deaths, 1986-2002

\begin{tabular}{lll}
\hline Date & Deaths & Average deaths per day \\
\hline July 4 & 1990 & 117 \\
December 23 & 1975 & 116 \\
January 1 & 1881 & 111 \\
July 3 & 1873 & 110 \\
December 24 & 1872 & 110 \\
December 22 & 1776 & 104 \\
August 3 & 1770 & 104 \\
August 6 & 1755 & 103 \\
August 4 & 1739 & 103 \\
November 1 & 1733 & 102 \\
\hline
\end{tabular}

occurred during October, November, and December. The day of the year that averaged the fewest pedestrian deaths was March 12 (11 per day).

Motorcyclists account for about $7 \%$ of the total crash deaths. Forty one percent of the motorcyclist deaths during 1986-2002 occurred during the summer months of June, July, and August. The 10 days of the year with the most motorcyclist deaths on average also were during the summer (table 5). The day with the most motorcyclist deaths on average was July 4 (18 per day). The day with the fewest motorcyclist deaths on average was December 27 (two per day).

Tables 6-9 summarize the results for some days with relatively high crash deaths (July 4, December 23, January 1, and August 6) as categorized by role of the person killed, age, and BAC. Results are compared with those for the two days occurring exactly one week before and one week after.

July 4 was the day of the year with the most deaths to both passenger vehicle occupants and motorcyclists. It also had more pedestrian deaths on average than either June 27 or July 11 (table 6). As compared with June 27/July 11, July 4 had greater proportions of age groups younger than 30 among deaths to both passenger vehicle occupants (56\% v $48 \%$ ) and pedestrians $(44 \% \vee 37 \%)$. For all three person categories, July 4 had a greater proportion of deaths involving high BACs than June 27/July 11 (41\% v 31\% overall).

December 23, the day with the second highest number of passenger vehicle occupant deaths and the third highest number of pedestrian deaths, did not exhibit different patterns of passenger vehicle occupant deaths compared with December 16 and 30 (table 7). Among pedestrians, however, December 23 had greater proportions of deaths involving high BACs ( $35 \% \vee 27 \%)$.

January 1 averaged the third highest number of passenger vehicle occupant deaths and the most deaths among pedestrians. New Year's Day had more pedestrian deaths than either December 25 or January 8 in each of the years

Table 4 Days of year with most pedestrian crash deaths, 1986-2002

\begin{tabular}{lll}
\hline Date & Deaths & Average deaths per day \\
\hline January 1 & 410 & 24 \\
October 31 & 401 & 24 \\
December 23 & 373 & 22 \\
December 20 & 357 & 21 \\
November 2 & 351 & 21 \\
October 26 & 350 & 21 \\
November 3 & 348 & 20 \\
November 10 & 344 & 20 \\
November 1 & 340 & 20 \\
December 18 & 339 & 20 \\
\hline
\end{tabular}

Table 5 Days of year with most motorcyclist crash deaths, 1986-2002

\begin{tabular}{lll}
\hline Date & Deaths & $\begin{array}{l}\text { Average deaths } \\
\text { per day }\end{array}$ \\
\hline July 4 & 303 & 18 \\
July 19 & 266 & 16 \\
July 5 & 247 & 15 \\
July 16 & 246 & 14 \\
August 1 & 243 & 14 \\
August 6 & 243 & 14 \\
August 9 & 243 & 14 \\
June 28 & 242 & 14 \\
July 2 & 240 & 14 \\
August 25 & 239 & 14 \\
\hline
\end{tabular}

1986-2002. January 1 also had a much greater proportion of deaths involving high BACs than December 25/January 8 ( $51 \%$ v 33\% overall) (table 8 ). As might be expected, given the increase in alcohol related deaths, January 1 also had more deaths between midnight and $6 \mathrm{am}$ than the comparison days ( $48 \%$ v $20 \%$ overall).

August 6 is not close to any national holiday, but it was among the days with the most deaths to both passenger vehicle occupants (table 3) and motorcyclists (table 5). As compared with the days one week before and after, August 6 was similar in the breakdown of deaths by age (table 9). There were slight differences in the proportion of motorcyclist deaths involving high BACs (40\% v 35\%). Overall, however, August 6 was very similar to the comparison days.

\section{DISCUSSION}

Results of this study illustrate the large toll exacted by motor vehicle crashes in the United States. However, not included are the much more frequent non-fatal injuries, which average more than 8000 per day, many of them severe. ${ }^{1}$ It is not surprising that there is substantial variation in numbers of fatalities by day of week, time of day, and season, primarily because driving exposure differs by these factors. One other factor that affects the distribution of fatalities is alcohol impairment, which is more frequent at night, on weekends, and on certain days of the year. This helps explain why July 4 and January 1 were among the days with the most fatalities.

July 4 had on average at least 12 more crash deaths per day than any other day of the year (table 2). Some of these additional deaths may have been due to increased travel, but a large part of it was likely due to alcohol impaired travel to and from picnics, fireworks, and other recreational activities. The proportion of deaths involving high BACs was much higher on July 4 than on the comparison days one week earlier and later.

December 23 was typical of other December days with regard to who died and when they died. However, for pedestrians at least there is some evidence of increased alcohol impairment. Depending on the day of the week, December 23 can be a high travel day or a day for celebrations. So the reasons for the high number of crash deaths on December 23 probably are a combination of increased travel and alcohol impairment.

Almost half of the crash deaths on January 1 occurred between midnight and 6 am, a period of light traffic on any other day. Furthermore, half of the deaths involved alcohol impairment. This percentage of high BAC deaths was relatively high in each of the 17 years studied, ranging from $42 \%$ in 1995 (a Sunday) to 61\% in 2000 (a Saturday). The increased alcohol consumption due to New Year celebrations especially affected pedestrians; $58 \%$ of the pedestrians dying 


\begin{tabular}{|c|c|c|c|c|c|c|c|}
\hline & \multirow[b]{2}{*}{ Date } & \multicolumn{3}{|c|}{ Age (years) } & \multicolumn{3}{|c|}{ BAC $(\%)^{*}$} \\
\hline & & $0-29$ & $30-54$ & $55+$ & 0 & $0.01-0.07$ & $0.08+$ \\
\hline Passenger vehicle & July 4 & 56 & 30 & 15 & 52 & 7 & 40 \\
\hline occupants & June $27 /$ July 11 & 48 & 30 & 23 & 63 & 6 & 31 \\
\hline \multirow[t]{2}{*}{ Pedestrians } & July 4 & 44 & 37 & 18 & 53 & 4 & 43 \\
\hline & June $27 /$ July 11 & 37 & 34 & 28 & 61 & 4 & 35 \\
\hline \multirow{2}{*}{ Motorcyclists } & July 4 & 51 & 43 & 7 & 43 & 11 & 47 \\
\hline & June $27 /$ July 11 & 51 & 44 & 5 & 49 & 10 & 41 \\
\hline \multirow[t]{2}{*}{ All deaths } & July 4 & 54 & 32 & 14 & 52 & 7 & 41 \\
\hline & June $27 /$ July 11 & 47 & 32 & 21 & 62 & 6 & 31 \\
\hline
\end{tabular}

had a high BAC. This accounts for January l having more pedestrian deaths than any other day of the year.

August 6, along with several other days in August, had relatively high numbers of passenger vehicle occupant and motorcyclist deaths. However, the pattern of deaths on August 6 was similar to that of deaths that occurred one week earlier or later. The increased number of deaths on August 6 was therefore probably due to increased recreational travel.

Six of the 10 days with the highest number of crash deaths occurred during holiday periods. Recognizing this trend, police agencies sometimes initiate traffic enforcement campaigns during holiday periods. Such campaigns, when well publicized, have been shown to temporarily reduce crash rates, especially those involving alcohol. ${ }^{89}$ Safety organizations also warn of the dangers of holiday travel, but this overlooks the reality that every day of the year results in many motor vehicle deaths. That is, on each of the 6209 consecutive days included in this study, an equivalent of a plane-load or more of people died on the roads.

There is not a large public outcry concerning this daily loss of life. Motor vehicle crash deaths are "statistical" deaths that, except for the occasional spectacular crash, do not resonate with the public. ${ }^{10}$ The highest number of people killed in a motor vehicle crash during the study period was 27 on Saturday, May 14, 1988. This particular crash, in which a driver with a measured BAC of $0.24 \%$ struck a busload of children, sparking a catastrophic fire, received nationwide attention. However, most deaths (94\%) occurred in crashes in which one or two people were killed, and these were scattered throughout the country. Daily tallies of fatal crashes in the United States are not available until many months have passed.
Motor vehicle crashes and injuries are often acknowledged to be a social problem, but part of the public indifference may reflect the fact that almost everyone is a driver. Risk perception research suggests that people create "illusory zones of immunity" around routine, everyday activities that are supposed to be under their control. ${ }^{11}$ Related to this is the belief held by most people that their driving skills are better than those of others. ${ }^{12}$ Thus although motor vehicle crashes may be recognized as a social problem, it is one that may be perceived as not particularly affecting them. Whatever the case, there exists a kind of public apathy about motor vehicle injuries, one result of which is that motor vehicle injury prevention efforts are woefully underfunded compared with other public health problems. ${ }^{13}$

These influences, however, can be overcome. Sweden, for example, adopted an approach called "Vision Zero" in 1997, with the ultimate goal of no fatal or serious injuries on the road. Included among Vision Zero principles are that the objective of a transport system is to move people without causing serious injury, there is no place for trade-offs between fatalities and benefits such as faster travel, and people have the responsibility to drive properly but should not sustain injury if they do not. ${ }^{14}$ Intervention components of Vision Zero include traffic calming in congested areas, reducing speeds to within the limits of vehicle crashworthiness, and separating vehicle traffic on two lane roads with cable barriers. Other countries have adopted similar strategies. The Netherlands has begun a "Sustainable Safety" program, based on the principles of functional, homogeneous, and predictable use of the road network by all parties. ${ }^{15}$ In other words, roads must be designed so as to promote cooperation among road users, and enforcement of traffic rules should ensure that cooperation.

Table 7 Percentage of crash deaths by age and blood alcohol concentration (BAC), December 23 and comparison days, 1986-2002

\begin{tabular}{|c|c|c|c|c|c|c|c|}
\hline & \multirow[b]{2}{*}{ Date } & \multicolumn{3}{|c|}{ Age (years) } & \multicolumn{3}{|c|}{ BAC $(\%)^{*}$} \\
\hline & & $0-29$ & $30-54$ & $55+$ & 0 & $0.01-0.07$ & $0.08+$ \\
\hline \multirow{2}{*}{$\begin{array}{l}\text { Passenger vehicle } \\
\text { occupants }\end{array}$} & December 23 & 42 & 34 & 24 & 63 & 5 & 32 \\
\hline & $\begin{array}{l}\text { December } 16 / \\
\text { December } 30\end{array}$ & 43 & 32 & 25 & 63 & 5 & 32 \\
\hline \multirow[t]{2}{*}{ Pedestrians } & December 23 & 21 & 39 & 39 & 60 & 5 & 35 \\
\hline & $\begin{array}{l}\text { December } 16 / \\
\text { December } 30\end{array}$ & 28 & 32 & 39 & 68 & 5 & 27 \\
\hline \multirow[t]{2}{*}{ Motorcyclists } & December 23 & 63 & 34 & 3 & 56 & 5 & 39 \\
\hline & $\begin{array}{l}\text { December } 16 / \\
\text { December } 30\end{array}$ & 42 & 54 & 4 & 54 & 11 & 35 \\
\hline \multirow[t]{2}{*}{ All deaths } & December 23 & 39 & 35 & 26 & 63 & 5 & 32 \\
\hline & $\begin{array}{l}\text { December } 16 / \\
\text { December } 30\end{array}$ & 41 & 33 & 26 & 64 & 5 & 31 \\
\hline
\end{tabular}


Table 8 Percentage of crash deaths by age and blood alcohol concentration (BAC), January 1 and comparison days, 1986-2002

\begin{tabular}{|c|c|c|c|c|c|c|c|}
\hline & \multirow[b]{2}{*}{ Date } & \multicolumn{3}{|c|}{ Age (years) } & \multicolumn{3}{|c|}{ BAC (\%)* } \\
\hline & & $0-29$ & $30-54$ & $55+$ & 0 & $0.01-0.07$ & $0.08+$ \\
\hline \multirow{2}{*}{$\begin{array}{l}\text { Passenger vehicle } \\
\text { occupants }\end{array}$} & January 1 & 54 & 33 & 13 & 42 & 8 & 50 \\
\hline & $\begin{array}{l}\text { December 25/ } \\
\text { January } 8\end{array}$ & 44 & 32 & 23 & 62 & 5 & 33 \\
\hline \multirow[t]{2}{*}{ Pedestrians } & January 1 & 34 & 41 & 24 & 37 & 5 & 58 \\
\hline & $\begin{array}{l}\text { December 25/ } \\
\text { January } 8\end{array}$ & 24 & 38 & 36 & 57 & 5 & 38 \\
\hline \multirow[t]{2}{*}{ Motorcyclists } & January 1 & 64 & 34 & 2 & 45 & 7 & 48 \\
\hline & $\begin{array}{l}\text { December 25/ } \\
\text { January } 8\end{array}$ & 54 & 41 & 5 & 53 & 6 & 42 \\
\hline \multirow[t]{2}{*}{ All deaths } & January 1 & 51 & 35 & 14 & 42 & 7 & 51 \\
\hline & $\begin{array}{l}\text { December 25/ } \\
\text { January } 8\end{array}$ & 42 & 33 & 24 & 62 & 5 & 33 \\
\hline
\end{tabular}

*BAC imputed for drivers and pedestrians; for passenger deaths, BAC of driver was used.

Table 9 Percentage of crash deaths by age and blood alcohol concentration (BAC), August 6 and comparison days, 1986-2002

\begin{tabular}{|c|c|c|c|c|c|c|c|}
\hline & \multirow[b]{2}{*}{ Date } & \multicolumn{3}{|c|}{ Age (years) } & \multicolumn{3}{|c|}{$\operatorname{BAC}(\%)^{*}$} \\
\hline & & $0-29$ & $30-54$ & $55+$ & 0 & $0.01-0.07$ & $0.08+$ \\
\hline \multirow{4}{*}{$\begin{array}{l}\text { Passenger vehicle } \\
\text { occupants } \\
\text { Pedestrians }\end{array}$} & August 6 & 47 & 30 & 23 & 60 & 6 & 34 \\
\hline & July 30/August 13 & 47 & 31 & 22 & 60 & 6 & 34 \\
\hline & August 6 & 40 & 31 & 28 & 62 & 4 & 35 \\
\hline & July 30/August 13 & 37 & 35 & 27 & 60 & 6 & 35 \\
\hline \multirow{2}{*}{ Motorcyclists } & August 6 & 51 & 44 & 5 & 52 & 8 & 40 \\
\hline & July 30/August 13 & 54 & 40 & 5 & 53 & 12 & 35 \\
\hline \multirow[t]{2}{*}{ All deaths } & August 6 & 47 & 32 & 21 & 60 & 6 & 34 \\
\hline & July 30/August 13 & 47 & 33 & 20 & 60 & 6 & 33 \\
\hline
\end{tabular}

The World Health Organization has recently focused attention on motor vehicle injuries by devoting World Health Day 2004 to road safety and publishing an extensive report on road traffic injury prevention. ${ }^{16}$ Among the interventions recommended by the report are proposals for increasing "the visibility of vehicles and vulnerable road users". Visibility seems to be a particular problem for pedestrians in the United States. The days of the year with the most pedestrian deaths during 1986-2002 occurred

\section{Key points}

- During the years 1986-2002 there were on average 117 deaths per day in motor vehicle crashes in the United States.

- There was a great deal of day-to-day variability in motor vehicle crash deaths, ranging from a low of 45 to a high of 252 .

- Certain seasons (summer, fall), days of the week (Saturday, Friday, Sunday), and times of day (afternoon, evening) had high concentrations of crash deaths.

- July 4 had on average at least 12 more crash deaths than any other day of the year, and many of these involved alcohol.

- January 1 had more pedestrian crash deaths than any other day of the year, and more than half of these involved alcohol. between late October and early January, precisely the season with the least amount of daylight. Encouraging pedestrians to wear colorful clothing and to use designated crosswalks has little effect on adults, especially those with their judgment impaired by alcohol. Instead, municipal governments should concentrate on increasing the illumination of streets and sidewalks near restaurants, bars, shops, and other areas catering to pedestrians.

The days of the year with the most motorcyclist deaths during 1986-2002 were all during the summer, when the weather is more accommodating of two wheeled vehicles. Good weather can also encourage motorcyclists (and other motor vehicle operators) to increase their speed. Motorcyclist fatalities have been increasing in the United States in recent years, with excessive speed cited as a major factor. ${ }^{17}$ Other factors include alcohol use, lack of proper licensure, and failure to wear helmets. Thus the most effective strategies for reducing motorcyclist deaths would seem to be a strengthening of laws regarding speeding, alcohol limits, licensure, and helmet use, along with increased enforcement.

Passenger vehicle occupant deaths tend to increase during periods of increased recreational travel. This type of travel may involve alcohol use and excessive speed, so again increased law enforcement is needed. Such travel, however, could also involve rural roads, driver distractions, and fatigue. As these factors increase the likelihood of driver error, it is essential for all roadways to have well lit and easily understood traffic signs. Driver error can never be completely eliminated, so roadside hazards such as trees and utility poles should be removed or cushioned. Finally, efforts to increase both the crash avoidance capability and crashworthiness of passenger vehicles should be continued. 


\section{ACKNOWLEDGEMENTS}

This work was supported by the Insurance Institute for Highway Safety. The authors thank Anastasios Markitsis for his assistance with the data processing.

\section{Authors' affiliations}

C M Farmer, A F Williams, Insurance Institute for Highway Safety, Arlington, Virginia, USA

\section{REFERENCES}

1 National Highway Traffic Safety Administration. Traffic safety facts, 2002. Report No DOT-HS-809-620. Washington, DC: US Department of Transportation, 2004.

2 Cerrelli EC. Crash, injury, and fatality rates by time of day and day of week Report No DOT-HS-808-194. Washington, DC: National Highway Traffic Safety Administration, 1995

3 Arnold R, Cerrelli EC. Holiday effect on traffic fatalities. Report No DOT-HS 807-1 15. Washington, DC: National Highway Traffic Safety Administration, 1987.

4 Harms PL. Driver-following studies on the M4 motorway during a holiday and a normal weekend in 1966. Report No RRL-LR136. Crowthorne, Berkshire, UK: Road Research Laboratory, 1968.

5 National Safety Council. Independence Day holiday period traffic fatality estimate, 2003. Itasca, IL: National Safety Council, 2003. Available at: http://www.nsc.org/public/issues/indday03.doc (accessed 28 October 2003)

6 Subramanian R. Transitioning to multiple imputation: a new method to impute missing blood alcohol concentration (BAC) values in FARS. Report No
DOT-HS-809-403. Washington, DC: National Highway Traffic Safety Administration, 2002

7 Federal Highway Administration. Traffic volume trends. Washington, DC, 2003. Available at: http://www.fhwa.dot.gov/ohim/tvtw/tvtpage.htm (accessed 29 October 2003)

8 Agent KR, Green ER, Langley RE. Evaluation of Kentucky's "You drink and drive, you lose" campaign. Report No KTC-02-28. Lexington, KY: Kentucky Transportation Center, 2002.

9 Ross HL. Britain's Christmas crusade against drinking and driving. J Stud Alcohol 1987;48:476-82.

10 Jenni KE, Loewenstein G. Explaining the "identifiable victim effect". J Risk Uncertain 1997; 14:235-57.

11 Douglas M. Risk acceptability according to the social sciences. New York: Russell Sage Foundation, 1985

12 Williams AF, Paek NN, Lund AK. Factors that drivers say motivate safe driving practices. J Safety Res 1995;26:119-24.

13 Institute of Medicine. Reducing the burden of injury. Washington, DC: National Academy Press, 1999.

14 Tingvall C, Haworth N. Vision Zero: an ethical approach to safety and mobility. Paper presented to the 6th Institute of Transportation Engineers international conference on road safety and traffic enforcement: beyond 2000. Melbourne: 6-7 September, 1999. Available at: http:// www.general.monash.edu.au/muarc/viszero.htm (accessed 28 April 2004).

15 Koornstra M, Lynam D, Nilsson G, et al. SUNflower: a comparative study of the development of road safety in Sweden, the United Kingdom, and the Netherlands. Leidschendam, Netherlands: SWOV Institute for Road Safety Research, 2002.

16 Peden M, Scurfield R, Sleet D, et al, eds. The world report on road traffic injury prevention. Geneva: World Health Organization, 2004.

17 Shankar U. Recent trends in fatal motorcycle crashes. Report No DOT-HS809-271. Washington, DC: National Highway Traffic Safety Administration, 2001 .

\section{LACUNAE}

\section{Clothing related burn injuries to children}

T he first full year of data from the US CPSC National Burn Center Reporting System, published in October, showed that gasoline and other flammable liquids are frequently involved in clothing related burns to children. In a new report, CPSC staff reviewed 209 children's clothing burn injury reports received from March 2003 through June 2004 and found that more than one half involved gasoline or other flammable liquids. Developed in cooperation with the American Burn Association and Shriners Hospitals for Children, the CPSC's National Burn Center Reporting System collects comprehensive reports on clothing related burns to children under age 15 from the 105 burn centers that treat children. These incidents involve the ignition, melting, or smouldering of clothing worn by children. To support this effort, the National Association of State Fire Marshals works cooperatively with CPSC to retrieve and preserve children's clothing involved in burn injuries-an action that greatly enhances the investigative process. Garments collected by fire officials are forwarded to CPSC headquarters for inspection. At the suggestion of the NASFM, a committee consisting of the National Volunteer Fire Council, National Fire Protection Association, the International Association of Fire Chiefs, and NASFM developed a protocol for use by "first responders" across the country. For each incident reported, the burn center provides CPSC with preliminary information on the incident. A CPSC investigator is assigned to the case to conduct an in-depth investigation, interviewing the victim when possible, as well as parents, fire officials, and medical personnel. All reports are reviewed and maintained in CPSC's epidemiological databases. The report, which can be downloaded from http://www.cpsc.gov/ cpscpub/prerel/prhtml05/05028.pdf, highlights that of the 213 victims, 179 were injured while wearing daywear. No incidents appear to have involved tight fitting children's sleepwear or infant garments sized 9 months or smaller. The most frequent ignition source was an outdoor fire, involved in 62 of the 209 incidents, followed by lighters in 37 of the incidents. More than one half (107) of the 209 incidents involved flammable liquids. Boys, ages 10 to 14, comprised most of the victims. Many of these incidents were also associated with outdoor fires. Gasoline was the most frequently reported flammable liquid involved in these incidents. 